УДК 331.105 .64

Громко Лілія, кандидат економічних наук, доцент, Східноєвропейський національний університет імені Лесі Українки, кафедра економіки, безпеки та інноваційної діяльності підприсмства, м. Луцьк; ORCID ID 0000-0001-9437-9071, e-mail: hromko.lilia@eenu.edu.ua

https://doi.org/10.29038/2411-4014-2020-02-114-120

\title{
КОРПОРАТИВНА КУЛЬТУРА ЯК КЛЮЧОВИЙ ЧИННИК РОЗВИТКУ ТОРГОВЕЛЬНОГО ПІДПРИЕМСТВА
}

У статті встановлено, що корпоративна культура $є$ специфічним продуктом діяльності і розвитку підприємства, виявляється в системі використовуваних цінностей, які розділяє весь персонал, завдяки цілеспрямованим діям суб'єкта управління 3 «прищеплення» працівникам єдиних культурних стереотипів поведінки. Систематизовано чинники, що впливають на формування корпоративної культури. Узагальнено принципи формування корпоративної культури, дотримання яких дозволяє провести організаційні зміни, не викликаючи у персоналу неприйняття і протидію їм.

Доведено, що найбільш вірогідним вектором необхідних організаційних змін в діяльності вітчизняних торговельних підприємств на сучасному етапі $€$ перехід від технократичного управління до організаційної демократії, що забезпечує підвищення організаційної ефективності на основі розвитку процесів самоорганізації та самоврядування. Виявлено, що корпоративна культура $є$ найважливішим фактором будь-яких змін на торговельних підприємствах.

Ключові слова: корпоративна культура, організаційні зміни, мотивація персоналу, індивідуалізація, команда, цінності.

Громко Лилия, кандидат экономических наук, доцент, Восточноевропейский национальный университет имени Леси Украинки, кафедра экономики, безопасности и инновационной деятельности предприятия, г. Луцк

\section{КОРПОРАТИВНАЯ КУЛЬТУРА КАК КЛЮЧЕВОЙ ФАКТОР РАЗВИТИЯ ТОРГОВОГО ПРЕДПРИЯТИЯ}

В статье установлено, что корпоративная культура является специфическим продуктом деятельности и развития предприятия, оказывается в системе используемых ценностей, которые разделяет весь персонал, благодаря целенаправленным действиям субъекта управления по «привитию» работникам единых культурных стереотипов поведения. Систематизированы факторы, влияющие на формирование корпоративной культуры. Обобщены принципы формирования корпоративной культуры, соблюдение которых позволяет провести организационные изменения, не вызывая у персонала неприятие и противодействие им.

Доказано, что наиболее вероятным вектором необходимых организационных изменений в деятельности отечественных торговых предприятий на современном этапе является переход от технократического управления к организационной демократии, обеспечивающей повышение организационной эффективности на основе развития процессов самоорганизации и самоуправления. Выявлено, что корпоративная культура является важнейшим фактором любых изменений на торговых предприятиях.

Ключевые слова: корпоративная культура, организационные изменения, мотивация персонала, индивидуализация, команда, ценности.

Liliia Hromko,

Associate Professor, Candidate of Economics,

Lesya Ukrainka Eastern European National University, Department of Enterprise Economics, Security and Innovative Activity,

Lutsk 


\section{CORPORATE CULTURE AS A KEY FACTOR IN THE DEVELOPMENT OF A TRADE ENTERPRISE}

Nowadays, the social and economic development of society has a clear focus on the growth of innovation, efficiency and competitiveness. Only employee, who possesses creative potential and the ability not only to reproduce their own workforce, but also to self-development, becomes a personalized asset for the organization and a determining factor in the success of society and each separate enterprise. Today, the attention is paid to the person who is considered a key resource of the company, and conditions for the realization of his/her potential and ability to work effectively are created.

Corporate culture is one of the most effective means of attracting and motivating employees of any commercial enterprise, which brings to it a very specific material result. In order to increase productivity of trade enterprises in market economy, it is necessary to improve not only quantitative indicators of their activities, but also qualitative, to develop a corporate culture, which is the key to profitability and competitiveness of modern enterprises.

The main purpose of the article is to find conceptual factors for improving the corporate culture of a commercial enterprise and also the analysis of corporate culture as a basis to increase of labor productivity.

The article establishes that corporate culture is a specific product of activity and development of the enterprise, that is performed in the system of used values, which are shared by all staff due to purposeful actions of the management to implement united cultural stereotypes. The factors, which influence the formation of corporate culture, are systematized. The principles of formation of corporate culture are generalized, which allows to carry out organizational changes by observing them, without causing rejection and opposition to them in the personnel.

It is proved that nowadays the most likely vector of necessary organizational changes in the activity of domestic trade enterprises is the transformation from technocratic management to organizational democracy, which provides increasing of the organizational efficiency based on the development of self-organization and self-managemant. It was found that corporate culture is the most important factor of any change in commercial enterprises.

Key words: corporate culture, organizational changes, staff motivation, individualization, team, values.

Постановка проблеми. На сучасному етапі соціально-економічний розвиток суспільства має чітку направленість на ріст інноваційності, ефективності та конкурентоспроможності. При цьому лише працівник 3 його творчим потенціалом, здатністю не лише до відтворення власної робочої сили, а й до саморозвитку, стає для організації персоніфікованим активом, визначальним фактором успіху суспільства і кожного окремого підприємства. Сьогодні увага звертається на людину, яка розглядається як ключовий ресурс компанії, i на створення умов для реалізації його потенціалу i здатності до ефективної роботи. Корпоративна культура - одна 3 найбільш дієвих засобів залучення і мотивації співробітників, будь-якого підприємства, а особливо торговельного. Корпоративна культура приносить господарюючому суб'єкту абсолютно конкретний матеріальний результат. Вищезазначені факти обумовлюють актуальність дослідження корпоративної культури як провідного чинника розвитку торговельного підприємства.

Аналіз останніх досліджень і публікацій. Питаннями дослідження змісту корпоративної культури займалися такі вітчизняні та зарубіжні дослідники, як М. Дмитренко, Г. Захарчин, С. Капітонов, Я. Пижинський, М. Семикіна, О. Синицький, М. Чепелюк, Н. Фіщук та інші. Аналіз праць вітчизняних і зарубіжних дослідників показує, що існуючі концепції корпоративної культури містять багато цінної інформації, системне осмислення якої дає підставу для побудови цілісної і несуперечливої концепції управління персоналом з урахуванням мотиваційних і культурних аспектів трудової поведінки, властивих працівникам вітчизняних торговельних підприємств в сучасних умовах.

Виділення невирішених раніше частин загальної проблеми. Незначний досвід вітчизняних торговельних підприємств у сфері управління корпоративною культурою, як однієї з головних сфер управління.

Виклад основного матеріалу. Термін «корпоративна культура» $є$ вельми багатогранним, що призводить до появи безлічі різних визначень цього поняття, не завжди співзвучних один одному за смисловим значенням. Розглядаючи визначення корпоративної культури, можна виділити найпоширеніші підходи до тлумачення цього поняття: корпоративна культура як соціальнопсихологічний портрет організації; як вираз іï цінностей; як кредо або символ віри організації; як 
стиль життя, що характеризує організацію; як проекція особистісних рис керівника на стиль життя організації; як філософія і ідеологія управління тощо [2, 8, 9].

Тлумачення поняття «корпоративна культура» зводять іiі, переважно, до переліку складових: цінності, вірування, принципи, думки, ритуали тощо. Це призводить, 3 нашої точки зору, до спрощеного тлумачення поняття корпоративної культури. Адже, як відомо, для визначення сутності будь-якого предмета або явища не досить простого перерахування складових частин. Тому, щоб не «перевантажувати» визначення перерахуванням всіх складових, важливо виділити ту 3 них, яка $є$ визначальною. Нам видається, що такою складовою, що утворює внутрішній «стрижень» корпоративної культури, є система цінностей, прийнятих на підприємстві.

3 огляду на висловлені міркування, корпоративна культура може бути визначена як специфічний продукт діяльності i розвитку підприємства, що виявляється в системі використовуваних цінностей, які розділяє весь персонал, завдяки цілеспрямованим діям суб'єкта управління 3 «прищеплення» працівникам єдиних культурних стереотипів поведінки.

Найбільш істотними ознаками корпоративної культури, які слід враховувати в практичному управлінні, є наступні:

1. Всеохоплюваність корпоративної культури. Корпоративна культура охоплює всі сфери управління i види управлінських дій, здійснюваних на підприємстві. Загальна культурна узгодженість в організації можливою завдяки тому, що всі аспекти організаційної діяльності, включаючи стратегії, системи винагород, стилі лідерства, підходи до керівництва персоналом тощо, мають акцент на одних і тих же організаційних цінностях.

2. Неформальність корпоративної культури. Корпоративна культура, сильна або слабка, що сприяє динамічному розвитку або перешкоджає змінам, присутній в будь-якій організації незалежно від того, наскільки люди усвідомлюють їі вплив. Організаційні цінності не завжди усвідомлюються в достатній мірі, але від цього вони не стають менш дієвими. У реальному поведінці і сформованих поглядах працівників організації завжди простежується закладений в них ціннісний, моральний підтекст.

3. Стійкість корпоративної культури. Ця характеристика пов'язана 3 таким загальним властивістю культури, як традиційність їі норм і інститутів. Люди приходять в організацію і йдуть, а культура залишається більш-менш стабільною. Становлення будь-якої корпоративної культури вимагає значних зусиль з боку керівників і підприємців. Але, будучи сформованими, цінності культури і способи їх реалізації набувають характеру традицій і зберігають стійкість протягом декількох поколінь працівників [1, с. 37].

Розглядаючи корпоративну культуру в практичному аспекті, важливо розуміти, що іій притаманні і деякі протиріччя. Основне протиріччя полягає в необхідності, 3 одного боку, підтримувати з їі допомогою традиції i, з іншого боку, - проводити зміни, відповідні вимогам мінливої внутрішнього і зовнішнього середовища. Традиції забезпечують стабільність, цілісність організації, злагодженість взаємодії і прихильність працівників до організаційних цілей. Але традиції можуть стати одночасно і фактором, що стримує зміни, який призупиняє розвиток, якщо вони вже не відповідають мінливим вимогам часу.

Один $з$ найбільш відомих розробників концепції корпоративної культури Е. Шейн вважає, що на кожному етапі життєвого циклу організації роль корпоративної культури може змінюватися. Так, на стадії становлення корпоративна культура «скріплює» підприємство, закріплює в свідомості працівників цінності, що сприяють досягненню успіху. На стадії середнього віку культура стає самостійним чинником життя організації, визначає політику в галузі управління персоналом, особливості взаємодії із зовнішнім середовищем, сприяє адаптації організації до мінливих зовнішніх умов. На стадії зрілості і, тим більше, занепаду культура може виявитися «каменем на шиї» організації, але настільки звичним, що від нього важко відмовитися, і тоді лідер повинен знайти в собі сили для перетворень [3, с. 145].

Корпоративна культура, будучи специфічним продуктом життєдіяльності підприємства, існує об'єктивно, незалежно від нашої волі і свідомості. Несучи в собі певні протиріччя, вона може сприяти, а може перешкоджати реалізації тих чи інших управлінських стратегій. Тому основне завдання 
керівництва в цій сфері полягає в свідомому впливі на корпоративну культуру і цілеспрямованому внесення в неї змін, що відповідають меті організаційного розвитку.

При цьому ключовими факторами, що визначають необхідність збереження і зміцнення або зміни корпоративної культури, які виступають у ролі зворотного зв'язку, з боку організації є організаційна ефективність,а з боку працівника - задоволеність працею.

На рис. 1 представлена схема, що демонструє основні чинники, які впливають на формування корпоративної культури. Ключова роль у формуванні корпоративної культури належить керівнику (або власнику підприємства) і його найближчому оточенню. Цілі та цінності, що розділяють вище керівництво організації, є тим початковим вихідним матеріалом, на основі якого здійснюється формування корпоративної культури. Оскільки будь-яка підприємство не $є$ ізольованим, керівництво змушене при формуванні корпоративної культури враховувати не лише власні цілі і цінності, а й вимоги, що ставить ринок і суспільство в цілому до діяльності об' єкта господарювання. Від того, як повно будуть враховані ці вимоги, залежить те, наскільки організація виявиться конкурентоспроможною і успішною.

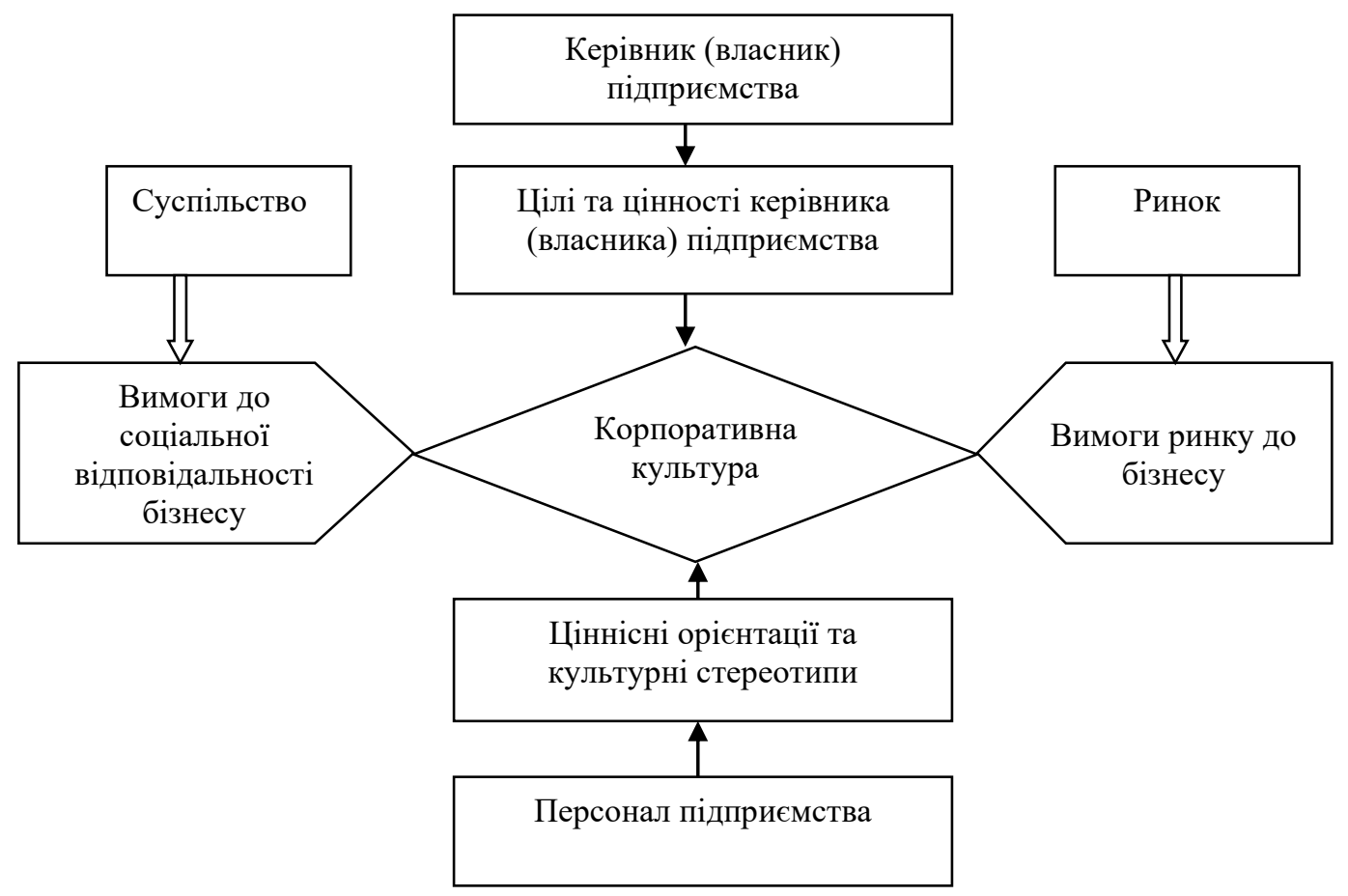

Рис. 1. Чинники, щьо впливають на формування корпоративної культури

При всій важливості зовнішнього фокуса корпоративної культури не варто забувати, що за всіма успіхами і досягненнями організації стоїть персонал.

Найважливішими факторами, які слід враховувати при формуванні корпоративної культури, $\epsilon$ ціннісні орієнтації та культурні стереотипи працівників організації. Формування корпоративної культури, по суті, зводиться до «прищеплення» єдиних цінностей всім працівникам організації. Тому зрозуміло, що успішність вирішення цього завдання в значній мірі залежить від того, наскільки проголошувані керівництвом організаційні цінності відповідають ціннісним орієнтаціям працівників і не суперечать їм. Протиріччя ціннісних орієнтацій працівників і того, що є найбільш цінним для керівництва організації, стає основним джерелом розчарувань, конфліктів і падіння продуктивності праці [8, с. 258].

На торговельних підприємствах останнім часом спостерігається процес інтелектуалізації: поведінкою персоналу керують правила, етичні норми, а не менеджери; широко застосовуються колективні методи прийняття рішень; практикується коучинг. Досвід роботи торговельних підприємств, які володіють сильною корпоративною культурою, показують як елементи культури відіграють іноді вирішальну роль у конкурентній боротьбі. Важливим чинником успіху 
корпоративної культури на торговельних підприємствах стає взаємозв'язок корпоративних принципів із загальними цілями діяльності.

Вважаємо, що корпоративну культуру торговельних підприємств варто будувати дотримуючись принципів моделі Ф. Харріса та Р. Морана. Дослідники пропонують будувати корпоративну культуру спираючись на такі характеристики: усвідомлення себе і свого місця на підприємстві; комунікативна система та мова спілкування; зовнішній вигляд і само презентація на роботі; харчові звички та традиції персоналу; усвідомлення часу, відношення до нього та його використання; взаємовідносини між людьми; цінності та норми; віра в цілі та прихильність до них; процес розвитку працівника та його навчання; етика на робочому місці та мотивація працівника [7].

3 точки зору демократії, яка передбачає в працівниках високий ступінь індивідуальності, творчості та особистої відповідальності, корпоративна культура покликана забезпечити високий рівень соціалізації персоналу в поєднанні з індивідуалізацією. Саме такий тип працівника є найбільш ефективним в умовах командної роботи на торговельному підприємстві. Тому корпоративна культура, побудована на цінностях організаційної демократії, повинна сприяти не тільки успішної соціалізації працівників, а й сприяти розвитку їх творчих починань, що є необхідною умовою командної роботи.

Вище ми описали найбільш загальний підхід до формування корпоративної культури і впровадження в життя підприємства нових цінностей, відповідних прийнятої стратегії розвитку суб'єкта господарювання. Але все нове часто викликає опір персоналу. Тому варто узагальнити принципи формування корпоративної культури, дотримання яких дозволяє провести організаційні зміни, не викликаючи у персоналу неприйняття і протидію їм. До основних таких принципів можна віднести наступні:

1. Інформування персоналу про заплановані зміни. Працівники повинні розуміти зміст нововведень, причому не лише з точки зору підприємства, але і їх особистих інтересів.

2. Впровадженню організаційних змін повинне передувати навчання кадрів, метою якого є не лише інформування про зміст позитивних і негативних аспектів нововведень, а й налагодження ефективних взаємовідносин з персоналом.

3. Необхідно дотримуватися умови поетапності здійснюваних нововведень. Хороший ефект може також дати проведення попереднього експерименту - впровадження нововведень в окремих підрозділах для перевірки як позитивних, так i негативних їх наслідків. Не можна одночасно здійснювати багато інноваційних програм.

4. Широке залучення персоналу, створення умов активної підтримки нововведень. Організаційні перетворення не матимуть успіху, якщо в процес змін не будуть залучені всі члени організації. Особливе значення має також підтримка нововведень «ключовими» людьми на підприємстві, залучення неформальних лідерів до здійснення змін;

5. Створення схильності персоналу до змін шляхом енергійної підтримки нововведень i працівників, що відповідають за їх впровадження; стимулювання тих співробітників, які найбільш повно втілюють у своїй діяльності проголошені цінності і принципи; заохочення поведінки, що сприяє змінам в бажаному напрямку.

6. Здійснення не тільки об'єктивних, але і символічних змін для закріплення на свідомому і підсвідомому рівні працівників організаційних цінностей через активне формування традицій, підтримки обрядів, використання гасел і символів підприємства - їі назви, уніформи, логотипів тощо.

7. Відмова від прямої критики минулого, так як це може бути багатьма сприйнято негативно, максимальне використання позитивних сторін минулого як грунту для «вирощування» майбутніх нових тенденцій.

8. Створення системи вимірювання та обліку результатів від нововведень, публічне визнання успіхів і досягнень, вшанування працівників i підрозділів, які зробили вагомий внесок в організаційний розвиток [4, с.21].

Як зазначалося вище, однією 3 найбільш істотних характеристик корпоративної культури є іiі всеохоплюваність: корпоративна культура охоплює всі сторони життєдіяльності підприємства. Тому при проведенні організаційних перетворень, спрямованих на зміну корпоративної культури, важливо визначити основні напрями прикладання зусиль.

Будучи вже сформованою, корпоративна культура виконує такі функції на підприємстві: 
1) функція ідентифікації - формує почуття приналежності до підприємства;

2) функція інтеграції - формує почуття причетності до спільної справи, сприйняття підприємства як деякого цілісного утворення, відмінного від інших аналогічних утворень;

3) функція суспільної пам'яті - забезпечує збереження і накопичення досвіду та традицій підприємства;

4) нормативно-регулююча функція - виконує роль найбільш ефективного механізму соціального регулювання трудових відносин, встановлюючи для всіх працівників організації загальні цінності і правила трудової поведінки. Завдяки використанню норм досягається стійке i

дієве регулювання трудової поведінки працівників, забезпечується надійність і передбачуваність поведінки, ії відповідність очікуванням;

5) комунікативна функція - забезпечує взаєморозуміння i взаємодію працівників завдяки прийняттю ними спільних цінностей;

6) адаптивна функція - сприяє виживанню підприємства в мінливих умовах;

7) виховно-світоглядна функція - формує уявлення працівників про своє місце і призначення на підприємстві, забезпечує правильне сприйняття етичних проблем;

8) пізнавально-інформаційна функція - дозволяє працівникам визначити, як вони повинні ставитися до оточуючої їх дійсності, чого слід очікувати від колег, керівників в тих чи інших ситуаціях;

9) іміджева функція - сприяє формуванню особливого образу підприємства, відрізняє ії від інших господарюючих суб'єктів;

10) мотиваційна функція - забезпечує найбільш ефективний вплив на колективну мотивацію персоналу [5].

Здійснюючи зазначені функції, корпоративна культура сприяє успішної соціалізації працівників торговельного підприємства. Під організаційною соціалізацією розуміється безперервний процес взаємодії працівника і його організаційного оточення, в результаті якого працівник визначає своє місце і роль на підприємстві, усвідомлює організаційні цінності і приймає встановлені в організації зразки рольової поведінки і методи виконання роботи.

Соціалізація працівників, що відбувається під впливом корпоративної культури не може в повній мірі виключити процеси індивідуалізації, а здійснюється паралельно 3 ними. 3 точки зору організаційної демократії, яка передбачає в працівниках високий ступінь індивідуальності, творчості та особистої відповідальності, корпоративна культура покликана забезпечити високий рівень соціалізації персоналу в поєднанні з індивідуалізацією. Саме такий тип працівника є найбільш ефективним в умовах командної роботи торговельного підприємства, тому його прийнято називати «член команди». Саме корпоративна культура, побудована на цінностях організаційної демократії, повинна сприяти не тільки успішній соціалізації працівників, а й сприяти розвитку їх творчого потенціалу, що є необхідною умовою командної роботи персоналу торговельного підприємства.

Запропонований у статті підхід до формування корпоративної культури визначає основні принципи та напрями зусиль, що забезпечують послідовну заміну технократичних цінностей в управлінні персоналом торговельних підприємств на цінності організаційної демократії. Практична реалізація такого підходу сприяє розвитку колективної мотивації до праці і підвищення на цій основі організаційної ефективності.

Висновки та пропозиції. Отже, відзначимо,що колективна діяльність створює сильнішу мотивацію до праці, ніж індивідуальна. Тому найважливішим завданням ефективного управління персоналом є формування колективних суб'єктів діяльності та розвиток колективної мотивації до праці. Колективним суб'єктом діяльності, що володіє найбільш потужним мотиваційним потенціалом саме для персоналу торговельного підприємства , $є$ команда - особливий тип робочої гурту, який характеризується розвиненими відносинами співпраці та особистої відповідальністю кожного члена групи за внесок в загальну справу. Найбільш очевидним вектором необхідних організаційних змін в діяльності вітчизняних торговельних підприємств на сучасному етапі $є$ перехід від технократичного управління до організаційної демократії, що забезпечує підвищення організаційної ефективності на основі розвитку процесів самоорганізації та самоврядування.

Насамкінець варто зазначити, що найважливішим фактором будь-яких змін на підприємствах, в тому числі й торговельних, є корпоративна культура. Цілеспрямоване і послідовне впровадження в 
діяльність господарюючого суб'єкта цінностей організаційної демократії сприяє успішної соціалізації працівників, розвитку колективної мотивації до праці і підвищення на цій основі ефективності діяльності торговельного підприємства.

\section{Джерела та література}

1. Дмитренко М. Й. Методологічні засади дослідження корпоративної культури у соціальнофілософському знанні. Гуманітарний часопис. 2011. № 1. С. 37- 41.

2. Захарчин Г. М. Корпоративна культура: навч. посібник . Львів: Новий світ. 2011. 122 с.

3. Капитонов Э. А., Зинченко Г. П. Корпоративная культура: теория и практика: учеб. пос. М. : АльфоПресс. 2015. $351 \mathrm{c}$.

4. Пижинський Я. І., Бустінов Д.В. Формування концепції організаційної культури. Экономика $и$ управление. № 5. 2008. С. $20-25$.

5. Семикіна М. В. Еволюція організаційної культури на українських підприємствах: проблеми та протиріччя . Держсава та регіони. Серія: Економіка та підприємнищтво. 2009. № 6. С. 197-200.

6. Синицька О.І. Корпоративна культура: типологізація, функції та критерії забезпечення у формуванні соціально-трудових відносин на ринку праці України. Науковий вісник Херсонського державного університету. Серія : Економічні науки. 2014. Вип. 5 (3). С. 255-261.

7. Структура и модели организационной культуры. URL: http://www.corpculture.ru/content/ctrukturaimodeli-organizatsionnoi-kultury (дата звернення: 01.05.2020).

8. Чепелюк М.І. Роль корпоративної культури підприємства в концепціях організаційних змін. Проблеми формування та реалізації конкурентної політики : матеріали III Міжнар. наук.-практ. конф., м. Львів, 19-20 верес. 2013 р. Національний університет «Львівська політехніка» [та інші]. Львів : АртDрук. 2013. С. 258-259.

9. Фіщук Н. Ю. Корпоративна культура організації: сутність, види, принципи та вплив на розвиток організації. Вісник Сумського наџіонального аграрного університету. Економічні науки. 2014. № 6 (24). С. 5665.

\section{References}

1. Dmytrenko M. Y. (2011) Metodolohichni zasady doslidzhennia korporatyvnoi kultury u sotsialnofilosofskomu znanni [Methodological bases of research of corporate culture in social and philosophical knowledge]. Humanitarnyi chasopys. 1, 37-41 [in Ukrainian].

2. Zakharchyn Gh. M. (2011) Korporatyvna kuljtura: navch. posibnyk [Corporate culture]. Ljviv: Novyj svit, 2011, 122 [in Ukrainian].

3. Kapytonov E. A. (2015) Korporatyvnaia kultura: teoryia y praktyka: ucheb. pos.[ Corporate culture: theory and practice]. M.: Alfo-Press [in Russian].

4. Pyzhynskyi Ya. I., Bustinov D.V. (2008) Formuvannia kontseptsii orhanizatsiinoi kultury. [Formation of the concept of organizational culture]. Ekonomyka y upravlenye. № 5, 20 - 25 [in Ukrainian].

5. Semykina M. V. (2009) Evoliutsiia orhanizatsiinoi kultury na ukrainskykh pidpryiemstvakh: problemy ta protyrichchia [Evolution of organizational culture at Ukrainian enterprises: problems and contradictions]. Derzhava ta rehiony. Seriia: Ekonomika ta pidpryiemnytstvo. 6, 197-200 [in Ukrainian].

6. Synytska O.I. (2014) Korporatyvna kultura: typolohizatsiia, funktsii ta kryterii zabezpechennia u formuvanni sotsialno-trudovykh vidnosyn na rynku pratsi Ukrainy [Corporate culture: typology, functions and criteria for providing in the formation of social and labor relations in the labor market of Ukraine]. Naukovyi visnyk Khersonskoho derzhavnoho universytetu. Seriia : Ekonomichni nauky. 5 (3), 255-261 [in Ukrainian].

7. Ctruktura y modely orhanyzatsyonnoi kulturb [Structure and models of organizational culture]. Retrieved from:: http://www.corpculture.ru/content/ctrukturai-modeli-organizatsionnoi-kultury [in Ukrainian].

8. Chepeliuk M.I. (2013) Rol korporatyvnoi kultury pidpryiemstva $v$ kontseptsiiakh orhanizatsiinykh zmin [The role of corporate culture of the enterprise in the concepts of organizational change]. Problemy formuvannia ta realizatsii konkurentnoi polityky : materialy III Mizhnar. nauk.-prakt. konf., [pp. 19-20] Natsionalnyi universytet «Lvivska politekhnika» [ta inshi]. Lviv : ArtDruk [in Ukrainian].

9. Fishchuk N. Yu. (2014) Korporatyvna kultura orhanizatsii: sutnist, vydy, pryntsypy ta vplyv na rozvytok orhanizatsii [Corporate culture of the organization: the essence, types, principles and impact on the development of the organization] Visnyk Sumskoho natsionalnoho ahrarnoho universytetu. Ekonomichni nauky, 6 (24), 56-65 [in Ukrainian]. 